https://doi.org/10.5719/aub-g/68.1/7

\title{
THE DYNAMICS OF TOURISM IN BĂILE GOVORA RESORT
}

\author{
ANA-MARIA ROANGHEȘ-MUREANU ${ }^{1}$ \\ AMALIA MIHAELA OGLINDOIU ${ }^{2}$
}

\begin{abstract}
The Romanian balneary potential is generous, especially at the level of the Vâlcea spa resorts. Represented by mineral water, sapropelic mud or Mofetta gases, balneary therapy has captured the attention of a significant number of tourists attracted by beneficial physical and mental effects.

Băile Govora is one of the Vâlcea resorts, whose hydromineral background has favored the development of the town, both from a tourist and economic point of view. The quality of mineral waters has been extensively studied, the benefits of mineral waters bringing the resort's reputation. From 1887 (the year when salt water was discovered) to the present day, the tourism at the level of the Băile Govora resort increased, a fact determined by the significant number of tourists. The accommodation and treatment infrastructure plays a very important role in the development of the resort. It is intended that the study highlight the necessity of tourism capitalization of the locality, by modernizing the exploitation units and the treatment base, and the exclusive spa promotion of the resort.

Keywords: mineral resources, tourism, accommodation infrastructure, treatment base, Băile Govora.
\end{abstract}

\section{Introduction}

Tourism is one of the most important components of the national economy. Romania enjoys a diversified tourist potential that has favored tourism in almost all areas of the country and especially in all forms (urban tourism, rural tourism, spa tourism, leisure tourism, etc.). Among these, balneary tourism is one of the most important because it aims both at promoting the natural potential of a region and the physical well-being of tourists, by providing both therapeutic and recovery treatments, as well as prophylactic treatments (addressed to healthy people but want to prevent a possible illness).

If in "European healthcare systems, spa resorts are important tourist destinations, especially for consumers who seek health and recreation equally"

Faculty of Geography, University of Bucharest, E-mail: ana_mureanu@yahoo.com

Faculty of Geography, University of Bucharest, E-mail: mihaelaoglindoiu@yahoo.com 
(Stăncioiu et al., 2013, p.128), in Romania this type of tourism focused on the use of mineral sources for treatment, meaning strictly on aspects of balneology.

\section{The conceptual framework}

The European Union gives great importance to tourism, which contributes substantially to the achievement of its economic and social objectives. In a speech by the Economic and Social Committee, the members of the EU Tourism Directorate stated that "tourism is, along with all its components, an opportunity to create new jobs" (Economic and Social Committee, 2003, p. 2).

The balneo-climatic product (called in modern and balneomedical terms) benefits from a concentration of natural factors used by using a wide range of procedures or treatments performed in a series of resorts. The French specialists use the notion of balneotherapy "representing the use of current water for therapeutic purposes (not the mineral, thermal or sea water)" (Rouzade, 1998). Also, the term "health tourism" is used, meaning the concept of "free time spent away from home where one of the goals is to improve health" (Clift S., Pag J., 1996).

In 1999, Erdeli G. et al. claimed that balneary tourism is "the type of tourism practiced in balneary-climatic resorts, for balneary purposes, profiled on the use of hydromineral resources, mofetes, etc." on a bioclimatic stimulus background, having the ultimate objective of treating the amelioration or prophylaxis of certain disorders".

Teleki, Munteanu and Bibicioiu (2004) were of the opinion that the health treatment "covers a number of other names used in our country and in other countries - spa tourism, health tourism, welfare treatment, cleaning primary prophylaxis " (p. 52). Hence, in order to have a spa tourism we must first benefit from mineral water and then from a suitable material base.

Health tourism was developed due to the modern human need to treat or prevent certain illnesses, but mainly due to the growth of occupational diseases and those from large cities heavily polluted (Iordache, Sârbu, Ciochină, 2016).

Compared to other forms in which tourism is easier to characterize, in the health system it is more difficult to identify its tourist functions. In the specialty literature, medical tourism is defined by using natural factors through multiple forms depending on the type of resource o the country-specific connotations. Thus, health tourism is a comprehensie concept, with numerous categories of activities that centrally (medical treatment) or indirectly (sauna, massage) involve health and care, all with inflection points to other forms of tourism: leisure, adventure, sports, medical care, wellness (Iordache, Sârbu, Ciochină, 2016, p. 308). 
In some studies, medical tourism is used as the equivalent term of health tourism, which can broadly be defined as proving efficient private medical care, in collaboration with the tourism industry, for patients in need of surgery and other forms of specialized treatment (Simon et al., 2010, p. 177).

Romania has rich and varied natural resources that can support the development of health tourism (Comănescu, Ielenicz, 2004, Aluculesei, 2015, Rusu, Rusu, 2015, Roangheș-Mureanu, Oglindoiu, 2015, Drăghici et al., 2016). At the national level the health tourism represents an opportunity for the sustainable development of the entire tourism sector, which involves the development of other forms of tourism and other economic sectors (Țuțui, 2016). The establishing of health tourism's contribution to the development of local economies is an important element in designing and implementing effective mangement strategies so that benefits lcoal communities are obvious (Drăghici et al., 2016, p. 387).

A health tourism dimension has been made, through which it has been tried to position it from the perspective of the tourism consumer, its needs, and the reasons for visiting the destination (Fig. 1).

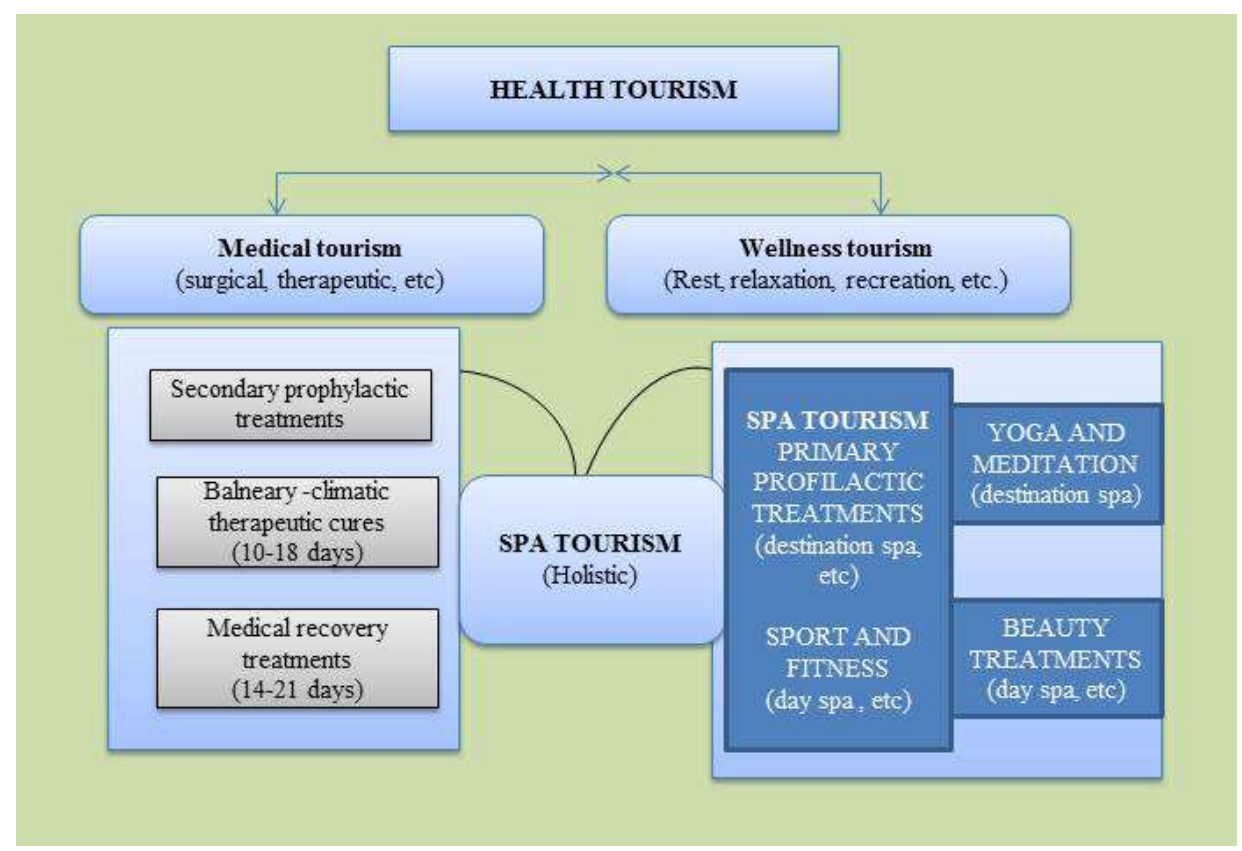

Figure 1. Dimensions of health tourism

(Source: Stăncioiu A.F and colab., 2013) 
Regardless of the name that it bears at both European and Romanian level, it is intended to improve the quality of tourism services, sustainable development, and to protect the interests of the tourists.

\section{Certification and development}

Băile Govora is a town located in Vâlcea county, which has 3 localities: Curăturile, Gătejeşti and Prajila, the acces being done on National Road 67, from Râmnicu Vâlcea-Horezu-Târgu Jiu. Although the first documents referring to the healing power of the Băile Govora waters date back to 1488, only in 1876 a local man (Gheorghe Ciurea) digs a shaft and finds that salty water comes out and cannot be drunk. A few years later (in 1886), Dr. Nicolae Popescu Zorileanu made his first visit to Govora, which made the beginning of the development of the locality. The first chemical analyzes were carried out, which showed the presence of iodine and sulfur in their composition, and so 1886 constituted the year of the beginning of the development of the Govora waters. In 1887, Govora was declared a spa resort, and in the March 1887 session of the Assembly of Deputies, the draft law on the development of some spa resorts was discussed.

Water quality has been extensively studied, the benefits of mineral water bringing the resort's reputation. The Bath establishment was built, followed by the organization of mineral springs. In 1895, the No. 1 and No. 2 hotels were completed, and in 1897 the Hotel no. 3 was completed. From an administrative point of view, until the establishment of the Băile Govora commune in 1908, the resort did not have a very clear situation, being claimed by both Govora and Păuşeşti Otăsău commune. The chlorinated-sodium, iodate, brominated, sulphurous, low-bicarbonate, hypotonic mineral waters, along with the sapropelic mud carried by Ocnele Mari, are used to treat a wide range of medical conditions within treatment bases achieved during this period of time.

Between 1914-1916 represented a period with difficulties in the evolution of the resort, being also the period of entry into war of Romania. Consequently, no investments were made by the state, "Govora-Călimăneşti" Society, in which there is a resort, with great efforts for modernization (146 cabins and bathing places were built within the Establishment, sewerage for all the buildings previously built, the pavilions were arranged, etc.).

On January 1, 1930, it was declared an urban commune, by Royal Decree 4036 of December 1929. The investments continued, the resort taking shape and attracting an increasing number of tourists.

In April 1948, the prefecture of Vâlcea County requested the Băile Govora Mayoralty to transfer to the State all the buildings and facilities belonging to the "Govora-Călimăneşti" society. After 40 years of operation, the company would be dismantled. This was also the new period for the resort, its 
activity being directed until 1989 on the development of tourist activities that were not addressed to the whole population, but only to the working class.

After 1990 there is a period of decline, the state no longer gives importance to the spa resorts, the privatization phenomena and the restitution of the buildings to the former owners began. The year 2007 comes with a new alternative, that of Romania's inclusion in the EU, which facilitates access to funds and reorientation towards spa treatment. At present, the rehabilitation of the spa segment is aimed at developing and promoting the existing mineral potential.

\section{Hydromineral potential in Băile Govora}

The basic element in the realization of the health tourism is the existence of mineral waters. The way of mineral water formation has been the object of study since the eighteenth century. In 1961-1973, the Institute for Recovery, Physical Medicine and Balneoclimatology carried out a more detailed study of each mineral and sludge water resource in Romania, the result of which is the existence of the four volumes entitled "Mineral waters and therapeutic sludges from S.R. Romania".

About the Băile Govora resort, it is known that it only began to be established in the last decades of the $19^{\text {th }}$ century, when the sulphurous waters of the Hinţa valley began to be exploited and transported to the Govora Monastery by the entrepreneur Gheorghe Ciurea (1876). When he digged a shaft, out of the ground came the so-called "burning water" (name given to the oil) and "salt water", which at first could not be used. Subsequent work on oil exploration would reveal the qualities of salt, iodine and sapropelic sludge, which Military Doctor I. Zorileanu recommends for the treatment of rheumatism. In 1878 iodine chlorosodic waters are also discovered. The first establishment for treatment took place in 1887 and had 29 hot bath cabins.

The mineral waters at Govora have a variable content of salts and minerals. Thus, there are salt-sulphurous, sulphurous waters, bicarbonate, calcium sulphate, magnesium waters.

Hydro-mineral deposits vary according to the type of mineralization, and are obtained from drillings and wells (Fig. 2).

\section{The existing accommodation and treatment infrastructure at Băile Govora resort}

The spa product involves the existence of specific facilities and endowments, focusing in particular on accommodation structures and treatment bases. The analysis of the two categories of statistical data was carried out taking into account the situation existing in 1990, 2000 and 2017 respectively. 
Accommodation infrastructure. The studies in the field have determined that "the most representative indicators of tourism, by means of which they quantify the tourism activity are: indicators of the offer (capacity of accommodation in operation - number of accommodation units and existing accommodation capacity - no. accommodation) and real and potential demand indicators (No. arrivals, no. overnight stays, average length of stay)". (Arionesei et al., 2016, p. 576)

The accommodation capacity in operation (number of units) shows a continuous decrease for the period 2000-2017, with values from almost 400,000 places to only 250,000 places. As far as the existing accommodation capacity is highlighted by the number of places, it is also decreasing (Fig. 2). The main reason that could be the basis for this continuous decrease would be: the decommissioning of some accommodation units, the change of the destination of some of the units changed into private property and especially the faulty management.

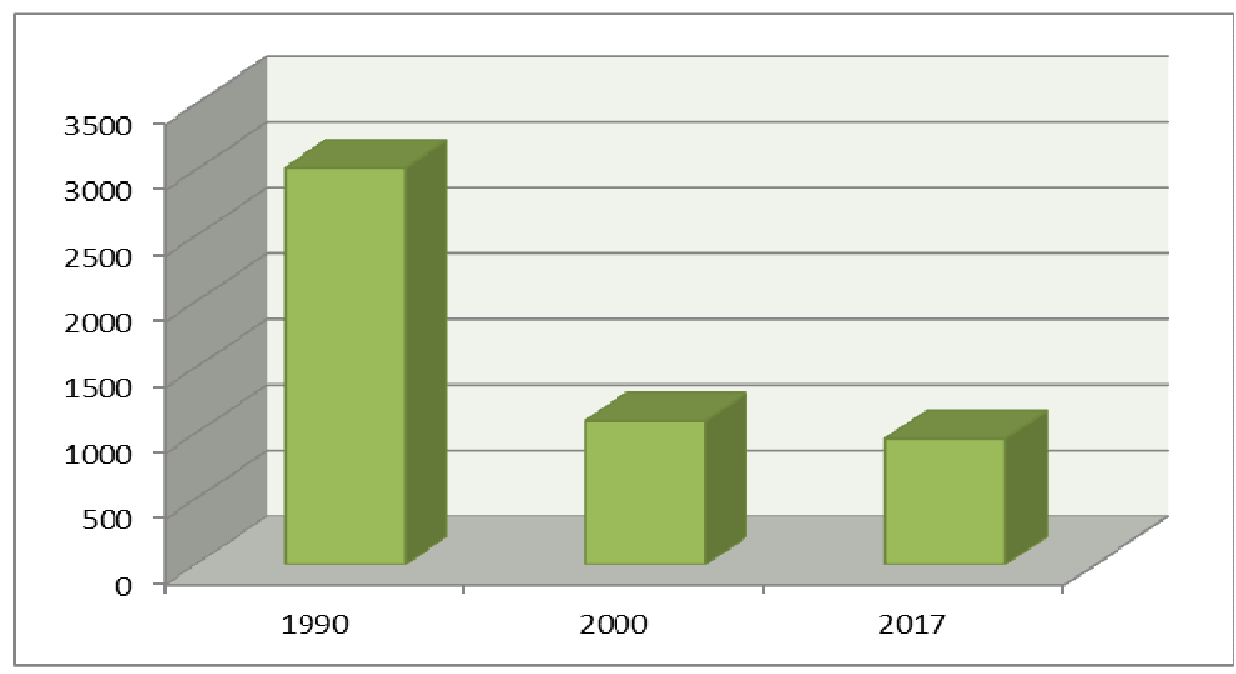

Fig. 2. Evolution of accommodation capacity - no. of places in accommodation units - at the level of Băile Govora (1990, 2000, 2017) (Source: NIS processing)

For the period 1990-2000, the statistical data are not conclusive, the NIS providing data only after 2000 , when the tourist groups in the resort are already decreasing to the level of 2017 (Fig. 3). 


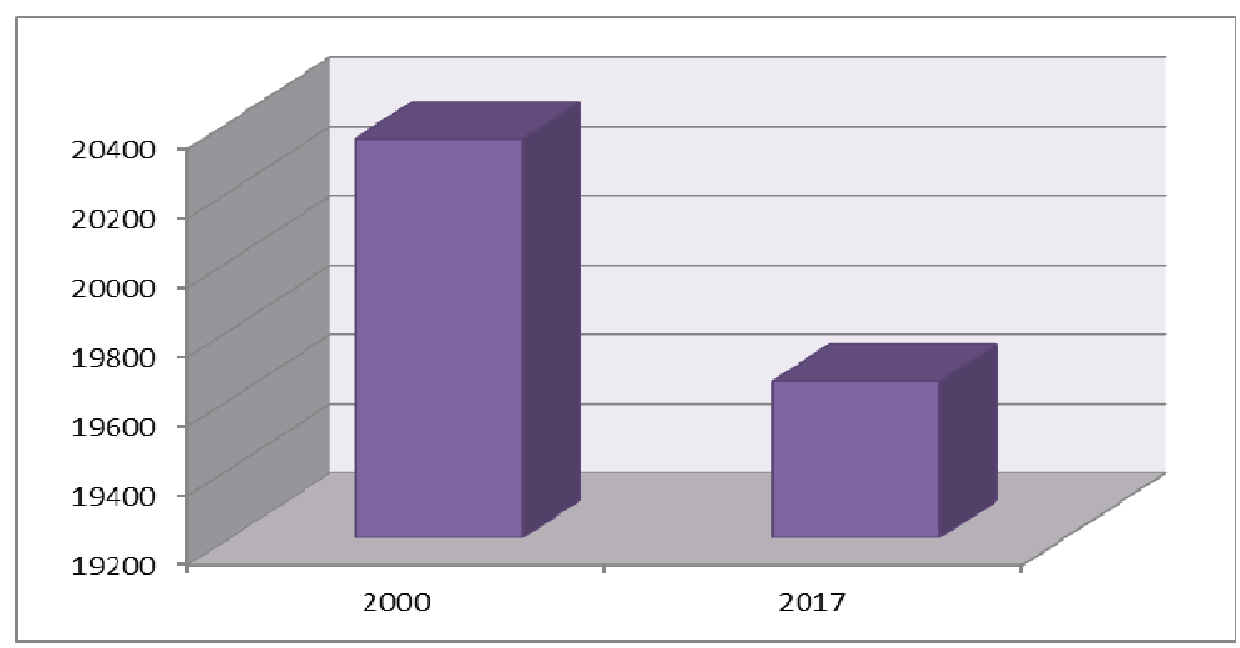

Fig. 3. Evolution of the number of arrivals in Băile Govora (1990, 2000, 2017) (Source: INS data processing)

If the number of arrivals did not drop by more than 1000 units, the same cannot be said for overnight stays where, in 2017, the decrease is even more pronounced, up to $50 \%$ of the total overnight stays in the year 2000 (Fig. 4).

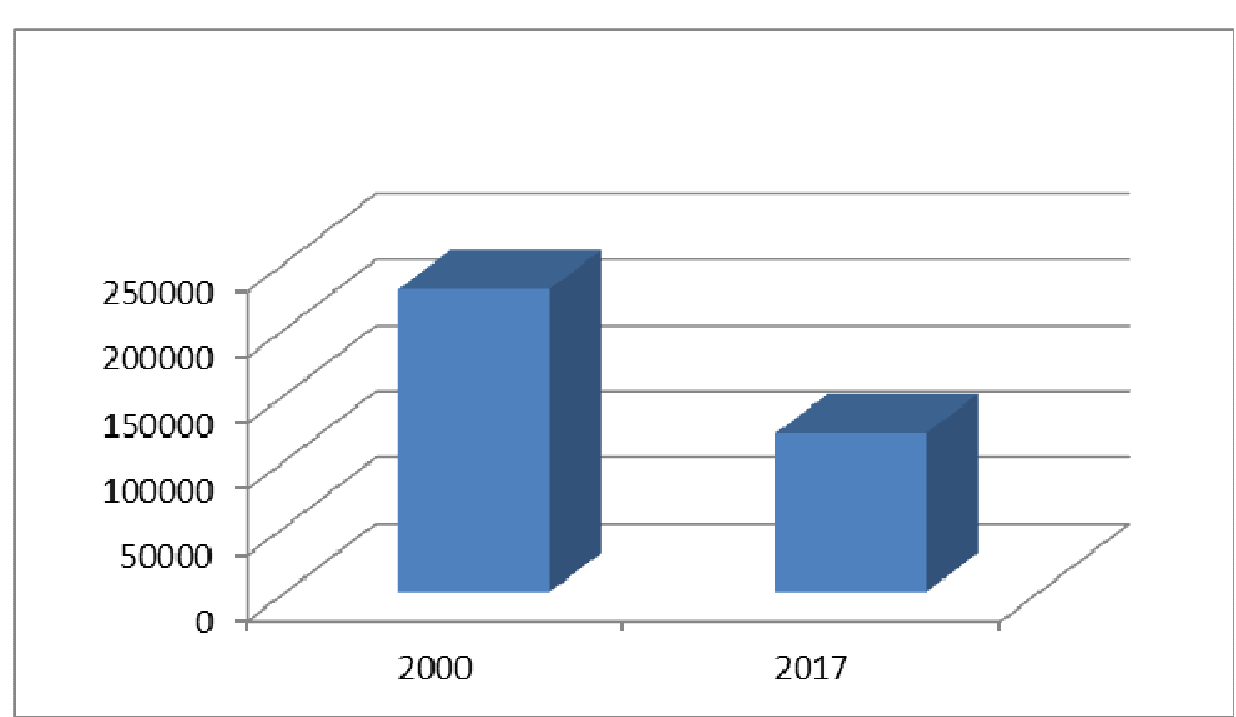

Fig. 4. Evolution of no. of overnight stays at Baile Govora resort (1990, 2000, 2017) (Source: INS data processing) 
Evolution of the index of use of the accommodation capacity, as ratio between the total number of overnight stays and no. of places at the resort level, also shows a decrease for the period 2000-2017. Given that this type of tourism is based on subsidy from the state budget, through tickets / treatment vouchers, this index also has a low value in the current economic background (Fig. 5).

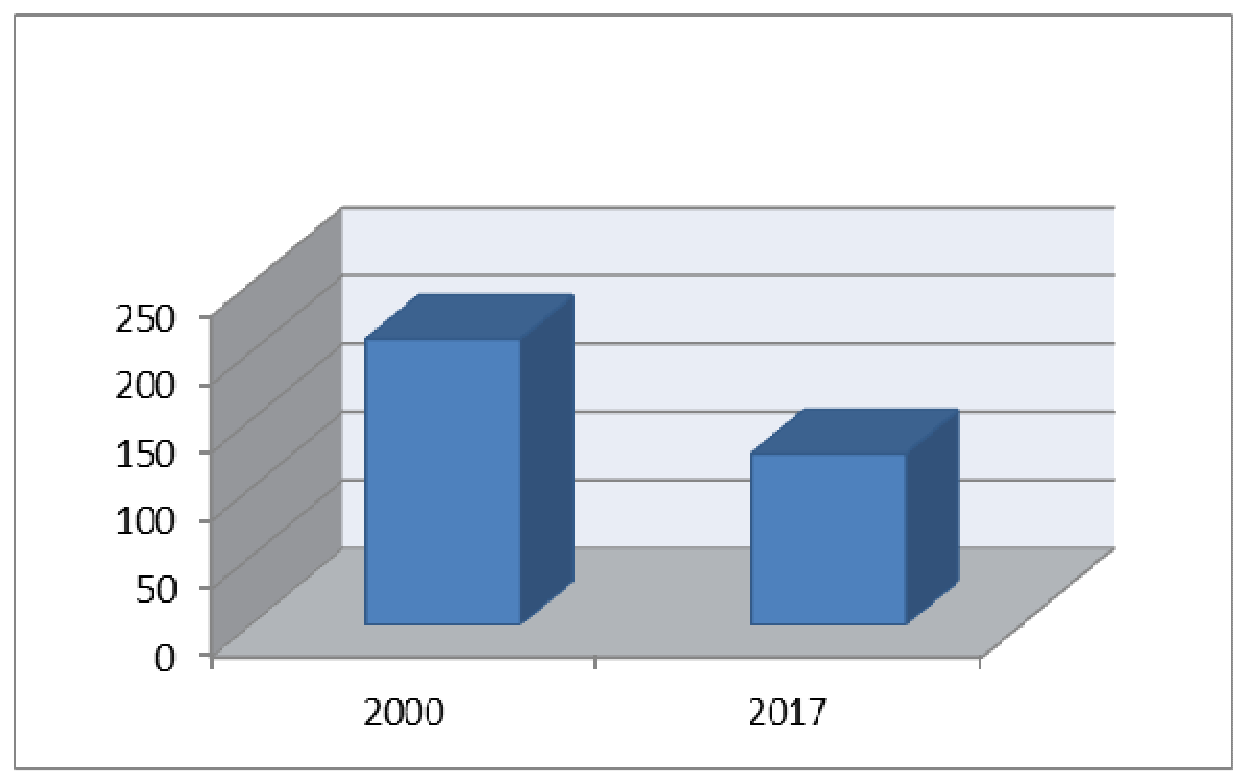

Fig. 5. Evolution of the use index of the accommodation capacity at Băile Govora resort (1990, 2000, 2017)

(Source: NIS data processing)

The fact that these decreases indicate the lack of development measures especially for the accommodation and treatment facilities, and implicitly the necessity of a strategy for this segment of the economy, which also consider the competitiveness of the operators in the spa sector.

The treatment infrastructure at the resort level operates either within the accommodation structure or separately in its own building. It is known the value of mineral waters present here, beneficial in the treatment of a wide range of diseases (Table 1). 
Existing mineral deposits in the resort of Băile Govora

\begin{tabular}{|c|c|c|c|}
\hline The spring & $\begin{array}{c}\text { Type of water of } \\
\text { the source }\end{array}$ & Way of usage & $\begin{array}{l}\text { The range of conditions } \\
\text { that can be treated }\end{array}$ \\
\hline Spring no. 1 & $\begin{array}{l}\text { Sulfuric } \\
\text { Sulfated }\end{array}$ & \multirow{14}{*}{$\begin{array}{l}\text { Internal } \\
\text { treatment } \\
\text { External } \\
\text { treatment }\end{array}$} & \multirow{14}{*}{$\begin{array}{l}\text { Respiratory disorders: } \\
\text { chronic bronchitis, } \\
\text { tracheobronchitis, bronchial } \\
\text { asthma, post-pneumonia } \\
\text { sequelae } \\
\text { ENT disorders: sinusitis, } \\
\text { laryngitis, rhinopharyngitis }\end{array}$} \\
\hline Spring no. 2 & Sodium & & \\
\hline Spring no. 3 & Sodium & & \\
\hline Shaft no. 1 & \multirow{6}{*}{$\begin{array}{c}\text { Sulfated } \\
\text { Chlorinated } \\
\text { Sulfuric } \\
\text { Sodium } \\
\text { Calcium }\end{array}$} & & \\
\hline Shaft no. 2 & & & \\
\hline Shaft no. 3 & & & \\
\hline Shaft no. 5 & & & \\
\hline Shaft no. 7 & & & \\
\hline Shaft no. 8 & & & \\
\hline Drilling 601 & $\begin{array}{c}\text { Chlorinated } \\
\text { Iodine }\end{array}$ & & \\
\hline Drilling 602 & Iodine & & \\
\hline Drilling 606 bis & Sodium & & \\
\hline Drilling 617 & $\begin{array}{l}\text { Chlorinated } \\
\text { Iodine }\end{array}$ & & \\
\hline Drilling 618 & $\begin{array}{l}\text { Sodium } \\
\text { Thermal }\end{array}$ & & \\
\hline
\end{tabular}

(Source: Data Processing Plan for Tourism Development in Romania 2007-2026)

Water replenishment would not be complete if there were not a number of installations that could be used for treatment, namely: Hot or cold bath installations; Installations for kinetotherapy. Procedures are particularly important and consist of inhalation therapy (ultrasonic insulosis, mineral water inhalation), mineral water baths, electrotherapy (low and medium frequency currents, ultrasound therapy, paraffin), kinetotherapy, massage, sauna, internal mineral water cleaning, field cleansing.

The medical infrastructure comprises: 2 individual medical practices, 1 allergy clinic, 1 polyclinic, 2 private pharmacies. In addition to these, there are the existing treatment bases in the accommodation structures, under the leadership and guidance of specialized medical staff.

Given the increase in the flow of tourists in the spa sector, it is important to understand the importance of approaching the system of treatment tickets at 
the resort level. According to the evolution of the number of specific treatment tickets in the spa resort of Băile Govora, settled by the National House of Pensions, the period 1993-2000 is a period of growth, and since 2014, there is a decrease, amid an increase in general attendance (Fig. 7).

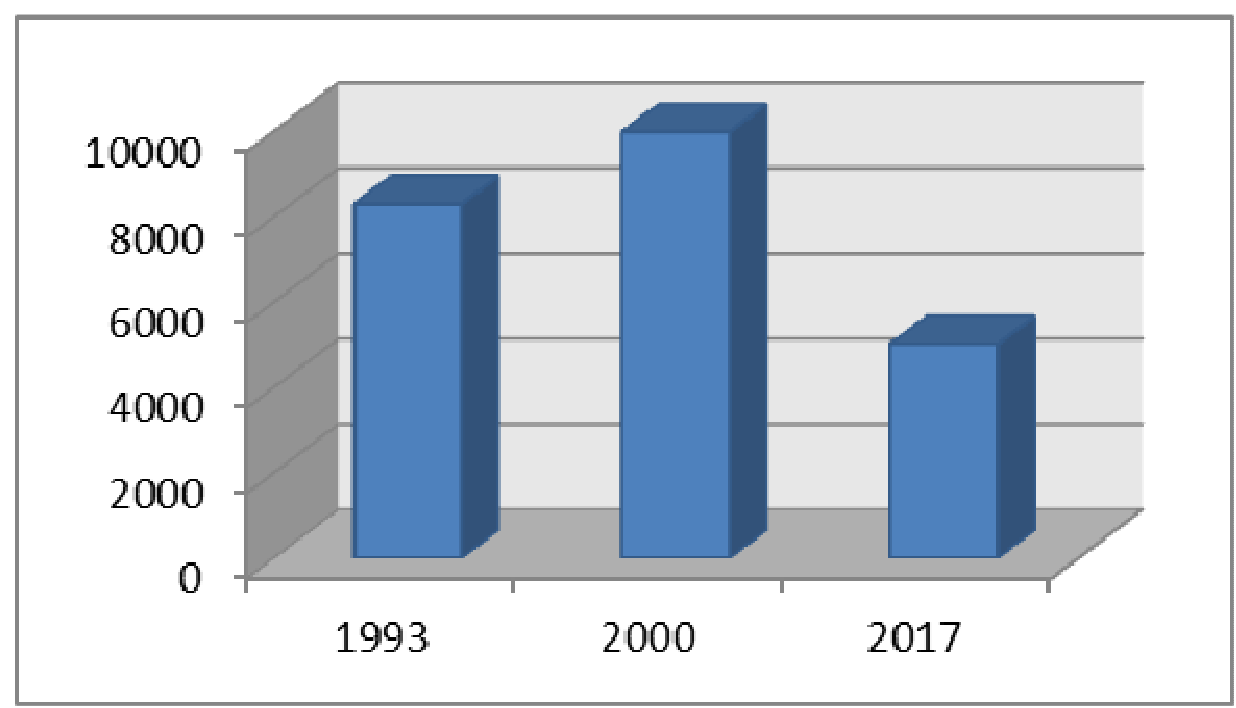

Fig. 7. Evolution of spa treatment tickets at the level of Băile Govora resort (Source: data processing INS + CNPP)

Considering the share of $3 / 4$ of arrivals of tourists compared to the number of treatment tickets, it can be concluded that the resort is losing to the category of customers benefiting from the state subsidy, in favor of wellness centers. However, the number of tickets is quite high, and this aspect of the treatment can still be rectified.

\section{Conclusions}

Through the study, a thorough evolution of the tourist activity at the level of the area was attempted, a statistical analysis that was carried out over a time horizon of approximately 28 years. The presence of a considerable number of hydromineral sources in the locality has facilitated both the development of an important part of the regional economy, namely tourism.

Although there are many weaknesses of spa tourism at the resort level, we consider that there are still prospects for expanding this form of tourism, and at the same time increasing both the interest of the Romanian tourists, especially the foreign ones, for the Romanian spa tourism products. 


\section{BIBLIOGRAPHY}

Aluculesei, A.C., 2015, 'Spa tourism - a comparative analysis on Spain and Romania', Balneo Research Journal, vol. 6, nr. 3, pp. 199-207.

Arionesei, G., Hapenciuc, C.V., Costea, M., 2016, 'Statistical confruntation of the evolution of tourism in the North East Region in comparison with the other regions of Romania', Amfiteatrul Economic, vol. 18 (Special Issue no.10), pp. 798-814.

Comănescu, L., Ielenics, M., 2004-2005, 'The relation/connection climate-touristic activities in Romania', The Annals of Valahia University of Târgoviște, Geographical Series, Tome 4-5, pp. 321-326.

Clift, S., Pag, J., 1996, Health and international tourist, Routledge, London and New York.

Drăghici, C.C., Diaconu, D., Teodorescu, C., Pintilii, R.-D., Ciobotaru, A.-M., 2016, 'Health tourism contribution to the struvtural dynamics of the territorial systems with tourism functionality', Procedia Environmental Sciences, Intenrational Conference Environment at a Crossroads: SMART approaches for a sustainable future, vol. 32, pp. 386-393.

Erdeli, G., Cândea, M., Costachie, S., Zamfir, D., 1999, Dictionary of human geography, Corint Publishing House, Bucureşti.

Iordache, C., Sârbu, A., Ciochină, I., 2016, 'Coordinates of developing the balneary tourism', management Strategies Journal, Constantin Brâncoveanu University, vol. 31, nr. 1, pp. 308-316.

Roangheș-Mureanu, A., Oglindoiu, A.M., 2015, 'Stratégies et politiques de promotion du tourisme balnéo-climatique dans le stations balnéaires dans le Souscarpates de Vâlcea', Annals od the University pf Bucharest, Geography Series, pp. 107-118.

Rouzad, G., 1998, La Thalassotherapie, Notes des conferences pour l'organisation Nationale de Tourisme de Sante, de Roumanie.

Rusu, T.A., Rusu, T., 2015, 'Reevaluationg the water resouces in tourism', Ecoterra Journal of Environmental Research and Protection, vol. 12, nr. 1, pp. 72-75.

Simon, T., Cândea, M., Tătaru A., Bogan, E. 2010, Rural tourism, urban tourism, Transversal Publishing House, Bucharest.

Stăncioiu, A.-F., Băltescu, C.-Al., Botoș, A., Pârgaru, I., 2013, 'Conceptual aspects regarding the spa tourism marketing in Romania', Theoretical and Applied Economics, vol. XX, no. 2 (579), pp. 145-158.

Teleki, N., Munteanu, L., Bibicioiu, S., 2004, Spa Romania - Guide for family doctors and specialist doctors, Bucharest.

Țuțui, D., 2016, 'Tourism development between potential and strategies. The case of balneary tourism', Analele Universității din Oradea, Fascicula Ecotoxicologie, Zootehnie și Tehnologii de Industrie Alimentară, vol. XV/A, pp. 123-130.

*** (2003) Economic and Social Committee, Opinion on the European tourism policy, Brussels, 24-25.

*** (1961-1973) Mineral waters and therapeutic muds in S. R. Romania, Institute of Balneology and Physiotherapy, Medical Printing press, Bucharest. 